Ansell N (in press) 'Shaping global education: international agendas and governmental power' International Development Policy Review

\title{
Shaping global education: international agendas and governmental power
}

\author{
Nicola Ansell \\ Brunel University \\ Nicola.ansell@brunel.ac.uk
}

\begin{abstract}
This paper takes as its starting point Bill Gould's (1993) People and education in the Third World, and examines changes in education systems in the Global South over the two decades since the book's publication. It focuses particularly on the role of global institutions and the ways in which they exercise control over and through education. Outlining the key processes shaping education in the 1980s and early 1990s and those operating today, the paper argues that global institutions increasingly operate through the subtle but pervasive technologies of power associated with neoliberal governmentality.
\end{abstract}

Bill Gould's (1993) People and education in the Third World was a path breaking text and in the 1990s proved an invaluable resource for understanding patterns of education around the world and the processes that were shaping them. In the introduction, Gould contrasts 'internal aspects' (the structure of the educational hierarchy, curriculum, quality of instruction, methods of assessment, design of buildings) with 'external aspects' (relationships to economic and social development, urban and rural change, fertility decline, agricultural innovation or technological improvement). The book is primarily concerned with the latter, in particular the relationship between education and development. Gould explores both how education affects people in their communities and wider societies, and the ways in which 'development' shapes education systems. He posits that education has been used in diverse ways by politicians and planners of different persuasions. Ghandi, Nyerere and Freire all saw revolutionary potential in education in their different continental settings, while global institutional actors such as UNESCO and the World Bank have sought to use education to further the diffusion of modernisation/capitalism from the West to the 'Third World'. Gould also charts alternative ways of conceptualising education's role in development, as necessary motor of change, a human right or 'an externally conceived phenomenon, based on an inappropriate Western model, for maintaining and reinforcing national and international inequalities and systems of dominance and hierarchical control' (p.4). Ultimately, he argues, 'education cannot be entirely separated from broader global issues, such as trading relationships, resource flows or industrial development, that are at the heart of the global development debate' (Gould, 1993:54).

This paper focuses on the shifts in global patterns, preoccupations with and influences on education systems in the Global South over the two decades since the book's publication. In particular, it explores the changing ways in which global institutions exercise control over and through education. 
Ansell N (in press) 'Shaping global education: international agendas and governmental power' International Development Policy Review

These, I argue, exemplify the increasingly subtle but pervasive technologies of power associated with neoliberal governmentality. I begin by outlining the global influences on education in the 1980s and early 1990s, as charted by Gould (1993), and then move on to consider six key processes shaping global education today. I conclude by exploring how these processes represent forms of governmental power.

\section{Global education, 1993}

Gould (1993) refers to an 'education revolution' in the latter half of the twentieth century when an unprecedented global expansion in schooling saw, for the first time, the majority of Third World children attending school, albeit sometimes only briefly. By the 1980s, however, serious challenges were emerging. Enrolment expansion had slowed and in some countries begun to fall; a situation attributed to economic decline as enrolments and GNP were strongly correlated in the late 1980s. Spending on education had risen but had not kept pace with enrolment. Moreover, the budget share spent on education fell dramatically as governments were forced to divert revenue to debt servicing: from $1972-86$ it declined from $15 \%$ to $10 \%$ in low income countries and $20 \%$ to $14 \%$ in middle income countries. Although global enrolment rates were converging, with poor countries devoting a smaller proportion of already small budgets to education the global gap in per capita education spending grew. This decline in per capita resources had a negative impact on quality.

Economic fortunes were not the only aspect of 'development' shaping education in the 1980s and 90s; the education-focused activities of global institutions were also influential. Gould (1993) explains that UNESCO had set the global educational agenda from 1950-75. Viewing education as a human right, it sought to narrow the global education gap, expand enrolments and improve quality through curriculum change and textbook development. Essentially, it sought to extend the Western experience of education worldwide. In the 1980s, however, agenda-setting shifted to the World Bank. The Bank had invested heavily in education from the 1960s, exercising influence through project loans and programme support. In the 1980s, however, debt-ridden countries were compelled to adopt Structural Adjustment Programmes and tie their domestic policies closely to Bank prescriptions.

The World Bank's thinking, dominated by economics rather than politics, sociology and educational theory, triggered an ideological shift away from equity as an objective (Gould, 1993). The Bank was not neglectful of education 'quality': it sought curricular change and stronger links to the demands of national economies. However, it also demanded reductions in per capita costs, to be achieved by raising pupil/teacher ratios; providing day rather than boarding schools at secondary level; and through more 'cost sharing' since if education is a worthwhile investment, it reasoned, beneficiaries should be willing to pay higher fees. The Bank also favoured decentralisation, was little concerned with extending spatial coverage and sought greater private sector involvement. As Gould (1993) points out, these measures were not consistent with improving equity.

Overall, Gould (1993) argues, the World Bank brought greater uniformity to education systems in the 1980s and 90s. Governments had few opportunities to develop their own ideas, as they could not fund them. They resented external domination but lacked power. Yet education systems and schools were not simply passive participants in a global agenda: experiences of education continued 
Ansell N (in press) 'Shaping global education: international agendas and governmental power' International Development Policy Review

to differ because policy implementation proved difficult for either governments or international institutions to control (Gould, 1993).

\section{Global education, 2014}

Since the early 1990s, many trends have continued, but there also have been some notable changes in direction. Below I examine six developments affecting education globally that were not apparent in the early 1990s and which represent new and more pervasive forms of control.

\section{Target setting}

A dominant trend in international development since the 1990s that has significantly influenced education has been the practice of target setting. The World Conference for Education for All (EFA) held at Jomtien, Thailand in 1990 became a key reference point for international discourse on education. The conference was another arena wherein the World Bank's agenda (increasing access to primary schooling) trumped UNESCO's broader vision of enhancing 'basic education' (King, 2007). It set a number of goals, the most prominent of which - the attainment of Universal Primary Education (UPE) by 2000 - proved overambitious. In 2000, the follow-up World Education Forum committed governments to a more clearly and narrowly defined set of six goals to be met by 2015 .

These two goal-setting conferences fed into the UN Millennium Summit and the formulation of its two education-focused Millennium Development Goals: to 'ensure that, by 2015, children everywhere, boys and girls alike, will be able to complete a full course of primary schooling'; and to 'eliminate gender disparity in primary and secondary education, preferably by 2005 , and in all levels of education no later than 2015' (UN, 2014). Like the EFA goals, these were drawn up by multinational agencies, with minimal involvement from Southern governments. Both sets of goals undoubtedly refocused multilateral institutions, aid agencies and national governments on extending access to primary education.

\section{Free Primary Education}

The EFA goals and MDGs did not emerge from nowhere: the impetus for increasing access lay primarily in human capital theory and the emergence of the 'knowledge economy'. With globalisation, the significance of human capital increases. Knowledge-based activities often contribute more to growing economies than material production, and labour markets are increasingly flexible, unstable and competitive. Hence education is increasingly considered crucial to gaining economic advantage.

Since the 1990s, the Post-Washington Consensus among the Bretton Woods institutions and other multilateral and bilateral donors has supported a boom in global investment in education. Costsharing has been abandoned in favour of Free Primary Education (FPE) policies. Many such policies are funded through the EFA Fast Track Initiative (FTI), a partnership between donors and developing countries, led by the World Bank, itself now the world's largest education funder. Under FPE, fees and other education-related costs such as charges for textbooks have been abolished in most low- 
Ansell N (in press) 'Shaping global education: international agendas and governmental power' International Development Policy Review

income countries, and primary school enrolment has expanded dramatically. The number of out-ofschool children of primary school age fell from 107 million in 1999 to 57 million in 2011 (UNESCO, 2014). In sub-Saharan Africa average primary Gross Enrolment Ratios rose from 78\% in 1990 to $97 \%$ by 2005 (Lewin, 2009), although progress has since stagnated (UNESCO, 2014). These outcomes of heavy investment appear to challenge Gould's (1993) observation that universal primary education might be practically impossible.

Some of the early FPE schemes faced difficulties. Dramatic increases in enrolment could not always be accommodated by the available classrooms or taught by the limited numbers of qualified teachers. In Malawi, for instance, where fees were eliminated in 1994, the gross enrolment rate in rural areas increased from $77 \%$ to $119 \%$ by $1997 / 8 .{ }^{1}$ However, there were about 120 students for every qualified teacher and 18,000 untrained teachers were employed, hence teaching methods were often poor (Al-Samarrai and Zaman, 2002). Aggregate enrolment statistics are often inflated by a concentration of children in Grade 1, swollen by those repeating the year. Some children do not proceed beyond Grade 1, and many fail to complete the four years considered the minimum to retain functional literacy (Lewin, 2009).

\section{Measuring and enhancing quality}

Over the past two years, a statistic has been widely circulated in official reports: while only 57 million children are out-of-school, 250 million remain unable to read and write by the time they should reach grade 4 (UNESCO, 2012). The reports infer that the emphasis on enrolment has been misguided: of 650 million primary school age children worldwide, it is said, 120 million do not reach grade 4, and a further 130 million remain in school but fail to acquire basic skills (UNESCO, 2012).

These stark statistics, which have provoked deep anxiety about education quality, reflect and feed a growing preoccupation with measuring education outcomes. Gould (1993) commented on the tests of the International Project for Evaluation of Educational Achievement (IEA) which were highly controversial and criticised for their emphasis on skill sets with a strong Western bias. Today, instruments such as the OECD's Programme for International Student Assessment (PISA) and Trends in International Mathematics and Science Study (TIMSS) are used to compare performance worldwide in literacy, mathematics and science among 15 year olds. Their use in lower- and middleincome countries reveals performance consistently below the OECD average, apart from in China and Vietnam (OECD, 2013). Regional instruments - SACMEQ (Southern and Eastern Africa Consortium for Monitoring Educational Quality), PASEC (Programme d'Analyse des Systemes Educatifs de la Confemen, used in Francophone countries), LLECE (Latin American Laboratory for Assessment of the Quality of Education) - show similarly low levels of skill acquisition among primary school leavers. Tests administered in Grade 2 of primary school found over $90 \%$ of children in Malawi, Mali, Zambia and Pakistan were unable to read a single word (OECD, 2012).

The significance attached to such data reflects research that shows economic growth correlates more strongly with achievement in standardised tests than with years of schooling (Tikly and Barrett,

\footnotetext{
${ }^{1}$ Gross enrolment ratio is the number of children enrolled in primary school divided by the number of primary school aged children in the population. When fees are eliminated, 'over-age' children are often enrolled in school for the first time, swelling the ratio above $100 \%$.
} 
Ansell N (in press) 'Shaping global education: international agendas and governmental power' International Development Policy Review

2011). Perhaps inevitably, efforts to improve test outcomes are driving global discourse and national policies. As Tikly and Barrett (2011) point out, standardised tests no longer merely measure achievement; they have come to define the very meaning of educational quality.

\section{Pedagogy, curriculum and beyond}

With donors becoming more directly involved with education policy and interested in quality, global thinking on curricula and pedagogy has gained influence. While UNICEF and some NGOs espouse child-centred learning as a means of democratising learning environments, rooted in a discourse of children's rights, such practices are also believed to enhance achievement and student retention (Sriprakash, 2010). Moreover, social constructivist approaches that privilege active, enquiry-based learning are consistent with a neoliberal vision of individual autonomy in a market system (Vavrus, 2009). A knowledge-based economy requires employees who can think independently.

In discussing education quality, the $\operatorname{OECD~(2012:45)~refers~to~'knowledge,~attitudes~and~skills'.~Many~}$ of the 'softer' skills and attributes acquired in school are delivered through a hidden curriculum, whereby schools seek to ensure their students develop particular behaviours and attitudes through the day-to-day organisation of the school. These might be dispositions such as respect for authority or competitiveness, values such as fairness, or pride in local culture.

In the past decade, international organisations have capitalised on the potential for schools to develop attributes in students beyond the academic curriculum. Schools are convenient places to deliver a range of interventions to large numbers of children. In AIDS-affected African countries, many schools provide lifeskills education, intended to compensate for perceived deficiencies in the raising of orphans and offer skills to avoid HIV infection (Ansell 2009). School feeding programmes are also popular for educational reasons (they encourage attendance and improve performance) and for their wider nutritional benefits (Bundy et al, 2009).

\section{Education systems reform: raising learning outcomes?}

The World Bank adopted a new strategy in 2011 focusing on 'learning for all'. This is a response to studies revealing the limits to expanding access and concerns about quality. The objective of enhancing human capital remains, recognising that 'growth, development, and poverty reduction depend on the knowledge and skills that people acquire, not the number of years that they sit in a classroom' (World Bank, 2011:3). Increasing expenditure has raised student/teacher ratios and increased textbook supply but appears not to have improved learning outcomes; hence donors believe it is necessary to look beyond inputs. Rather than focus on curriculum and pedagogy alone, the intention is to reform national education systems.

The term 'education system' typically refers to the public schools, universities, and training programs that provide education services. In this strategy, 'education system' includes the full range of learning opportunities available in a country, whether they are provided or financed by the public or private sector (including religious, nonprofit, and for-profit organizations). It includes formal and nonformal programs, plus the full range of beneficiaries of and stakeholders in these programs - teachers, trainers, administrators, 
Ansell N (in press) 'Shaping global education: international agendas and governmental power' International Development Policy Review

employees, students and their families, and employers. It also includes the rules, policies, and accountability mechanisms that bind an education system together, as well as the resources and financing mechanisms that sustain it. (World Bank, 2011: 5)

While this approach is in its infancy, the World Bank and other donors are exploring the impacts of teacher training reforms, use of performance incentives, innovations such as group learning, the provision of ICT as well as reforms to governance and accountability. Interest is extending beyond primary provision into other sectors. There is a growing recognition that specific policies and interventions interact with contextual dynamics in complex ways, but the problems of education systems are still conceived as technical rather than political.

\section{Privatisation and corporate influence}

The World Bank's Post-Washington Consensus education policies encompass both competitivenessdriven and finance-driven reforms (Tarabini, 2010). Beyond investing in improving access, quality or education systems, they embrace the classic elements of neoliberalism: liberalisation, privatisation and deregulation. These are enforced through Poverty Reduction Strategy Papers, prepared as a requirement for debt relief but also required for the Fast Track Initiative and by many bilateral donors. The other Bretton Woods institutions pursue similar policies: IMF SAPs continue to push for a reduced role for the state, while the WTO views education as a service and is eager to create a free global market in education.

In the early 1990s, Gould (1993) drew attention to the World Bank's growing enthusiasm for privatisation which has continued with the growth of private schooling for both rich and poor in many countries. Today, however, corporate capital is becoming involved. Under the WTO's General Agreement on Trade in Services (GATS), which entered into force in 1995, countries are required to open their 'education markets' to inflows of private capital. One major player in the global education market is Pearson. Among many other education services, Pearson operates low-cost fee-paying schools in Africa and Asia. It owns Bridge International Academies, a chain of 130 schools in Kenya with over 50,000 students that charges $\$ 5$ a month. Bridge operates a standardised curriculum, with scripted lesson plans, delivered by tablet, which detail what teachers should do and say at every moment of each class. The tablets are also used to monitor lesson pacing, record attendance and track assessment (CEI, 2014). In 2012 Pearson invested $f 10$ million in Omega schools (Tran, 2012), a chain of for-profit schools serving 12,000 students from nursery to Junior High School in Ghana. Students pay $\$ 0.75$ a day and, like Bridge, Omega operates a 'school-in-a-box' approach with standardised operations manuals and teaching materials. Teachers are senior high school graduates who receive one week of pre-service training and 2-3 days per term of in-service training (CEI, 2014). Both Bridge and Omega are among 22 private school chains supported by the Center for Education Innovations which is funded by the UK's Department for International Development (CEI, 2014). Despite the seemingly low cost of such provision, studies suggest low cost private education exacerbates inequality, with children from rural areas and lower socioeconomic backgrounds underrepresented and a widening gender gap (Woodhead et al, 2013).

\section{Interpreting the changes: the rise of governmentality}


Ansell N (in press) 'Shaping global education: international agendas and governmental power' International Development Policy Review

Over the past two decades, global development actors have adjusted the ways in which they shape education and through it the lives of young people. While in the 1990s, the World Bank exercised influence directly through the dictates of structural adjustment programmes, as well as through aid for particular programmes and innovations, global influence is now somewhat subtler and less direct. There has arguably been a shift from what Foucault (2007) referred to as disciplinary power to forms of governmentality, characteristic of neoliberalism. For Dean (2010), governmentality concerns the 'administration' of the collective body of society, and how society is regulated through the self-control of populations. Self-governing subjects, amenable to neoliberal society, are produced by fostering suitable behaviours and the appropriate use of freedom. While Foucault's focus was on the exercise of power by the state, more recent research has examined relations of governmentality between states, notably in the exercise of international development. As Ilcan and Phillips (2010:846) outline, 'development operates as a ruling apparatus and gives rise to technologies, experts and apparatuses for the administration and transformation of many peoples' lives and for courses of action aimed at the global South'.

Governmentality involves managing and monitoring both 'the conducts of individuals and the qualities of populations' (Huxley, 2007: 185). These joint processes can be observed in most of the developments described above. In terms of controlling the qualities of populations, the use of technocratic, rational planning alluded to by Gould (1993) is increasing. Target setting through the EFA goals and MDGs represents a techno-scientific means by which the conduct of populations is standardised (Ilcan and Phillips, 2010). International 'learning outcome' measures such as PISA operate in a similar way. Moreover, through these processes global actors manage and monitor the conduct of national governments (see Marandet, 2012). Through calculative technologies rather than the disciplining measures of previous decades, governments are driven to strive for particular outcomes; they are rendered responsible for carrying out plans to achieve the MDGs as quickly and efficiently as possible (Ilcan and Phillips, 2010). The emphasis on rational, technocratic planning is also apparent in the emerging focus on education systems, and in innovations such as life-skills education, through which population health is governed.

Second, education is envisaged as a means of moulding populations, and in particular creating the self-governing, aspirational subjects that the global neoliberal economy requires. Innovations in curriculum and particularly constructivist pedagogies and enquiry-based learning are considered desirable because they produce autonomous individuals, suited to the knowledge-based economy (Vavrus, 2009). The desired outcome here is less likely as forms of pedagogy wherein teachers relinquish power tend to generate resistance. It also conflicts with the emergence of the low-cost corporate 'school-in-a-box' which is target-driven and allows little teacher autonomy. Such schools arguably represent a 'race-to-the-bottom' in global human capital development, providing cheap low-skilled labour rather than potential knowledge economy entrepreneurs.

At the end of his book, Gould (1993) argues for models of education that are 'more locally ordered, more related to local cultural realities and aspirations, and more flexible in their delivery' (p.210). Education would be less driven by formal qualifications, there would be more non-formal and adult education, and radical curricula catering for people's needs in their everyday lives. Today the prospects for such change seem very remote. Even in countries that are relatively powerful with radical governments, education systems are being bought up by multinational corporations offering less diversity, less flexibility and a stronger orientation to global economic forces. In 2010, Pearson 
Ansell N (in press) 'Shaping global education: international agendas and governmental power' International Development Policy Review

bought Sistemas do Brasil, an integrated learning system that includes curriculum design, teacher support and training, print and digital content, technology platforms, assessment and other services. It now delivers education to 450,000 Brazilian students in both private and government sectors (Pearson, 2010).

Lastly, all these processes have implications for education and development research. Gould's (1993) distinction between internal and external aspects of education systems is no longer justifiable. Global actors are intervening purposefully in 'internal' aspects, and thereby shaping education's wider relationships with society and the economy. To understand these processes, explicit attention to political economy is required, along with greater emphasis on ethnographic approaches, rather than the predominantly quantitative and econometric research on which Gould (1993) had to rely and which continues to dominate education research globally.

\section{References}

AL-SAMARRAI, S. and ZAMAN, H. (2002) The changing distribution of public education expenditure in Malawi (Working Paper 29) World Bank, Washington.

ANSELL, N. (2009) 'Embodied learning: responding to AIDS in Lesotho's education sector' Children's Geographies, 7(1), 21-36.

BUNDY, D., BURBANO, C., GROSH, M., GELLI, A., JUKES, M. and DRAKE, L. (2009) 'Rethinking school feeding: social safety nets, child development and the education sector' World Bank, Washington DC.

CEI (2014) Low-Cost Private Schools, http://www.educationinnovations.org/topics/low-cost-privateschools (accessed 11/03/2014).

DEAN, M. (2010) Governmentality: power and rule in modern society, Second edition, Sage, London.

FOUCAULT, M. (2007) Security, territory, population: lectures at the Collège de France, 1977-78, Palgrave Macmillan, Basingstoke.

GOULD, W.T.S. (1993) People and education in the Third World, Longman, Harlow.

HUXLEY, M. (2007) 'Geographies of governmentality', in J.W. Crampton and S. Elden (eds) Space, knowledge and power: Foucault and geography, Ashgate, Aldershot.

ILCAN, S. and PHILLIPS, L. (2010) 'Developmentalities and calculative practices: the Millennium Development Goals', Antipode, 42(4), 844-874.

KING, K. (2007) 'Multilateral agencies in the construction of the global agenda on education', Comparative Education, 43(3), 377-391,

LEWIN, K. (2009) 'Access to education in sub-Saharan Africa: patterns, problems and possibilities', Comparative Education, 45(2), 151-174, 
Ansell N (in press) 'Shaping global education: international agendas and governmental power' International Development Policy Review

MARANDET, E. (2012) 'Governing through freedom, ruling at a distance: neoliberal governmentality and the new aid architecture in the AIDS response in Malawi', (unpublished PhD thesis), Brunel University

OECD (2012) Global Education Digest 2012, UNESCO Institute for Statistics, Montreal.

OECD (2013) 'PISA 2012 Results in Focus: What 15-year-olds know and what they can do with what they know', www.oecd.org/pisa (accessed 25/02/2014).

PEARSON (2010) Pearson and Sistema Educacional Brasileiro agree strategic partnership: Pearson to acquire SEB's school learning systems business http://www.pearson.com/news/2010/july/pearson-and-sistema-educacional-brasileiroagree-strategic-partne.html (accessed 11/03/2014).

SRIPRAKASH, A. (2010) 'Child-centred education and the promise of democratic learning: Pedagogic messages in rural Indian primary schools', International Journal of Educational Development, 30, 297-304.

TARABINI, A. (2010) 'Education and poverty in the global development agenda: Emergence, evolution and consolidation', International Journal of Educational Development, 30, 204212.

TIKLY, L. and BARRETT, A. (2011) 'Social justice, capabilities and the quality of education in low income countries', International Journal of Educational Development, 31, 3-14.

TRAN, M. (2012) 'Pearson to invest in low-cost private education in Africa and Asia' The Guardian 3 July http://www.guardian.co.uk/global-development/2012/jul/03/pearson-invest-privateeducation-africa-asia (accessed 10/03/2014).

UN (2014) Millennium Development Goals http://www.un.org/millenniumgoals/ (accessed 11/03/2014).

UNESCO (2012) EFA Global Monitoring Report: Youth and skills: putting education to work, UNESCO, Paris.

UNESCO (2014) EFA Global Monitoring Report 2013/4:Teaching and learning: achieving quality for all, UNESCO, Paris.

VAVRUS, F. (2009) 'The cultural politics of constructivist pedagogies: Teacher education reform in the United Republic of Tanzania', International Journal of Educational Development, 29(3), 303-311.

WOODHEAD, M., Frost, M., James, Z. (2013) 'Does growth in private schooling contribute to Education for All? Evidence from a longitudinal, two cohort study in Andhra Pradesh, India', International Journal of Educational Development, 33(1), 65-73.

WORLD BANK (2011) Learning for All: Investing in People's Knowledge and Skills to Promote Development, World Bank Group Education Strategy 2020, World Bank, Washington. 